\title{
A phase I study of subcutaneously administered aflibercept (VEGF trap) in a new formulation in patients with advanced solid tumors
}

\author{
Andrea Wang-Gillam • William P. Tew • Mace L. Rothenberg • Jakob Dupont • \\ Wendy Cooper • Lars Sternas • Giliane Buzenet • Jeffrey A. Sosman • \\ David R. Spriggs • Albert Craig Lockhart
}

Received: 12 August 2011 / Accepted: 29 September 2011 /Published online: 15 October 2011

(C) The Author(s) 2011. This article is published with open access at Springerlink.com

\begin{abstract}
Summary Targeting angiogenesis is a valid anti-cancer strategy. Aflibercept is designed to sequester circulating vascular endothelial growth factor (VEGF) by preventing VEGF from binding to its receptors. This phase I study was to evaluate a new formulation of subcutaneously administered aflibercept in patients with advanced solid tumors. Here we report our experience with the toxicity, pharmacokinetic profile and efficacy of the new $100 \mathrm{mg} / \mathrm{mL}$ subcutaneous (SC) formulation of aflibercept administered at a dose of at $4 \mathrm{mg} / \mathrm{kg}$ every 2 weeks.
\end{abstract}

Keywords Phase I study · Aflibercept · Angiogenesis inhibitor $\cdot$ Subcutaneously administration

\footnotetext{
A. Wang-Gillam • A. C. Lockhart $(\bowtie)$

Washington University School of Medicine,

660 South Euclid Ave, Campus Box 8056, St. Louis, MO 63110, USA

e-mail: alockhar@dom.wustl.edu
}

W. P. Tew $\cdot$ J. Dupont $\cdot$ D. R. Spriggs

Memorial Sloan-Kettering Cancer Center,

New York, NY, USA

\section{J. Dupont}

Currently employed at Genentech. Inc,

San Francisco, CA, USA

M. L. Rothenberg $\cdot$ W. Cooper $\cdot$ J. A. Sosman

Vanderbilt University Medical Center,

Nashville, TN, USA

L. Sternas · G. Buzenet

Sanofi-Aventis Oncology,

Bridgewater, NJ, USA

M. L. Rothenberg

Pfizer, Inc.,

235 East 42nd Street,

New York, NY, USA

\section{Introduction}

Angiogenesis is a hallmark for tumorigenesis [1], and vascular endothelial growth factor (VEGF) is a crucial mediator for this process. VEGF binds to its receptors, VEGF receptor 1 (VEGFR1) and VEGF receptor 2 (VEGFR2) to trigger cell proliferation, migration and metastasis [2, 3]. Agents blocking the VEGF axis have been successfully used as anti-cancer therapies.

Among various approaches to targeting angiogenesis, inhibiting VEGF ligand and receptor interactions has been the most successful [4]. To prevent VEGF from binding to its receptors, aflibercept (VEGF Trap; Regeneron Pharmaceutical and Sanofi-Aventis Pharmaceuticals) was developed for sequestering circulating VEGF. Aflibercept is a soluble protein that fuses the second immunoglobulin (Ig) domain of the VEGFR1 and the third Ig domain of the VEGFR2 to the Fc domain of human Ig G1 [5]. Antitumor activities of aflibercept have been demonstrated in preclinical studies and in recent clinical trials [6-14]. In clinical studies, aflibercept has been administered via an intravenous (IV) or subcutaneous (SC) route. Tew et al reported a phase I study using an aflibercept $\mathrm{SC}$ formulation of $25 \mathrm{mg} / \mathrm{mL}$ in patients with refractory solid tumors. In that study, the maximum tolerated dose (MTD) of aflibercept was not reached due to the volume of the drug to be administered via the $\mathrm{SC}$ route [12]. To achieve the SC administration of a higher dose of aflibercept, a new formulation of $100 \mathrm{mg} / \mathrm{mL}$ was generated and tested along with the IV formulation in a separate phase I study. It was determined that the SC dose should be $4 \mathrm{mg} / \mathrm{kg}$ every 2 weeks because of the similar bioavailability of aflibercept via the SC and IV routes. Lockhart et al reported on the toxicity data, pharmacokinetic profile and efficacy results of the IV formulation of aflibercept, and a dose of $4 \mathrm{mg} / \mathrm{kg}$ administered every 2 weeks was recommended for 
further phase II or III trials [11]. Here, we report our experience with the toxicity, pharmacokinetic profile and efficacy of the new $100 \mathrm{mg} / \mathrm{mL} \mathrm{SC}$ formulation of aflibercept administered $\mathrm{SC}$ at $4 \mathrm{mg} / \mathrm{kg}$ every 2 weeks.

\section{Methods}

Eligibility The study was a phase I clinical trial evaluating aflibercept IV and SC formulations in patients with refractory solid tumors at Vanderbilt University Medical Center and Memorial Sloan-Kettering Cancer Center. Results from the IV cohort have been published previously. The same eligibility criteria were used for the IV and SC cohorts, and were reported previously [11].

Drug dosage and administration Lyophilized aflibercept (200 mg) in a $20-\mathrm{mL}$ glass vial was reconstituted under sterile conditions by addition of $2.3 \mathrm{~mL}$ water for $\mathrm{SC}$ injection to ultimately produce a concentration of $100 \mathrm{mg} / \mathrm{mL}$. Aflibercept was stored at $2-8^{\circ} \mathrm{C}$. Aflibercept $4.0 \mathrm{mg} / \mathrm{kg}$ was administered SC every 2 weeks using a 0.3 or $1.0 \mathrm{~mL}$ syringe with a fixed 29 -gauge needle. Dose reduction to $3.0 \mathrm{mg} / \mathrm{kg}$ and/or $2.0 \mathrm{mg} / \mathrm{kg}$ was allowed for protocol specified toxicity. The body sites for injections were rotated between the anterior abdominal wall, the deltoid region and the anterior thigh. To ensure uniformity of drug absorption, all patients received the first injection to the anterior abdominal wall.

Pharmacokinetics Plasma samples were drawn after each drug administration. Plasma concentrations of free aflibercept and aflibercept: VEGF complexes ("bound aflibercept") were measured by direct enzyme-linked immunosorbent assay (ELISA) methods, as previously published [11]. The limits of quantitation of free aflibercept and bound aflibercept were $31 \mathrm{ng} / \mathrm{mL}$ and $44 \mathrm{ng} / \mathrm{mL}$, respectively.

Immunogenicity Immunogenicity testing was performed by measuring the presence of anti-aflibercept antibodies via ELISA 2 months after the last dose of aflibercept.

Toxicity and efficacy Patients were observed on a regular basis for toxicities which were graded by the National Cancer institute Common Terminology Criteria for Adverse Events (version 3.0). Dose limiting toxicity (DLT) was defined previously [11]. Tumor response was assessed by RECIST criteria every two cycles by magnetic resonance imaging (MRI) or computed tomography (CT). Patients continued in the study until disease progression, unacceptable toxicity or consent withdrawal occurred.

Statistical methods Descriptive statistics including median, minimum, maximum and percentage were used in this study.

\section{Results}

Demographic information A total of 13 patients were screened for the SC cohort; 10 patients were enrolled and received $4 \mathrm{mg} / \mathrm{kg}$ of aflibercept every 2 weeks. Demographic data are listed in Table 1. The median age for the cohort was 58 years. Of the 10 patients receiving $4 \mathrm{mg} / \mathrm{kg}$ every 2 weeks, 8 were female. Five out of the 10 patients had ovarian cancer as their primary tumors. The median number of prior regimens was 2.5. Median treatment duration was 30 days with the maximal duration being 184 days. Two of the 10 patients received $11-13$ doses of aflibercept.

Toxicity The safety-evaluable population was defined as patients who received at least one dose of aflibercept. Among 10 patients treated at $4 \mathrm{mg} / \mathrm{kg}$ every 2 weeks, 9 patients $(90 \%)$ experienced a treatment-emergent event that was possibly related to aflibercept. Most toxicities were grade 2 or less and resolved upon drug discontinuation. The common toxicities attributed to aflibercept at $4 \mathrm{mg} / \mathrm{kg}$ every

Table 1 Patient demographic and clinical characteristics

\begin{tabular}{|c|c|}
\hline Characteristic & $\begin{array}{l}N=10 \\
\text { No. }(\%)\end{array}$ \\
\hline \multicolumn{2}{|l|}{ Age, years } \\
\hline Median & 58 \\
\hline Range & $37-75$ \\
\hline \multicolumn{2}{|l|}{ Gender } \\
\hline Female & $8(80 \%)$ \\
\hline Male & $2(20 \%)$ \\
\hline \multicolumn{2}{|c|}{ Performance status (ECOG) } \\
\hline 0 & $5(50 \%)$ \\
\hline 1 & $4(40 \%)$ \\
\hline 2 & $1(10 \%)$ \\
\hline \multicolumn{2}{|l|}{ Tumor type } \\
\hline Ovary & $5(50 \%)$ \\
\hline Liver & $3(30 \%)$ \\
\hline Breast & $1(10 \%)$ \\
\hline Headhead and neck & $1(10 \%)$ \\
\hline \multicolumn{2}{|l|}{ Prior chemotherapy } \\
\hline Median & 2.5 \\
\hline Range & $1-12$ \\
\hline \multicolumn{2}{|c|}{ Treatment duration (days) } \\
\hline Median & 30 \\
\hline Min: Max & 15: 184 \\
\hline \multicolumn{2}{|c|}{ Number of doses administered } \\
\hline 2 Doses & $3(30.0 \%)$ \\
\hline 4 Doses & $4(40.0 \%)$ \\
\hline 6-10 Doses & $1(10.0 \%)$ \\
\hline 11-13 Doses & $2(20.0 \%)$ \\
\hline
\end{tabular}


Table 2 Common adverse events and severe adverse events (Grade 3/4) possibly related to aflibercept SC $4 \mathrm{mg} / \mathrm{kg}$

\begin{tabular}{|c|c|c|}
\hline \multirow[t]{2}{*}{ Adverse Event } & \multicolumn{2}{|c|}{ Patients $(N=10)$} \\
\hline & $\begin{array}{l}\text { All Grade } \\
\text { No. } \%\end{array}$ & $\begin{array}{l}\text { Grade } 3 / 4 \\
\text { No. } \%\end{array}$ \\
\hline General disorder and administration site & $7(70 \%)$ & - \\
\hline Fatigue & $7(70 \%)$ & - \\
\hline Early satiety & $1(10 \%)$ & - \\
\hline Edema peripheral & $1(10 \%)$ & - \\
\hline $\begin{array}{l}\text { Musculoskeletal and connective } \\
\text { tissue disorder }\end{array}$ & $7(70 \%)$ & - \\
\hline Arthralgia & $4(40 \%)$ & - \\
\hline Myalgia & $4(40 \%)$ & - \\
\hline Back pain & $2(20 \%)$ & - \\
\hline Joint stiffness & $1(10 \%)$ & - \\
\hline Muscle spasms & $1(10 \%)$ & - \\
\hline Muscular weakness & $1(10 \%)$ & - \\
\hline Musculoskeletal pain & $1(10 \%)$ & - \\
\hline Pain in extremity & $1(10 \%)$ & - \\
\hline $\begin{array}{l}\text { Respiratory, thoracic and mediastinal } \\
\text { disorders }\end{array}$ & $7(70 \%)$ & - \\
\hline Dysphonia & $7(70 \%)$ & - \\
\hline Nasal dryness & $2(20 \%)$ & - \\
\hline Dyspnea & $1(10 \%)$ & - \\
\hline Dyspnea on exertion & $1(10 \%)$ & - \\
\hline Nasal congestion & $1(10 \%)$ & - \\
\hline Cough & $1(10 \%)$ & - \\
\hline Pharyngolaryngeal pain & $1(10 \%)$ & - \\
\hline Gastrointestinal disorders & $5(50 \%)$ & - \\
\hline Nausea & $4(40 \%)$ & - \\
\hline Constipation & $2(20 \%)$ & - \\
\hline Abdominal pain & $1(10 \%)$ & - \\
\hline Diarrhea & $1(10 \%)$ & - \\
\hline Glossodynia & $1(10 \%)$ & - \\
\hline Oral pain & $1(10 \%)$ & - \\
\hline *Vascular disorder & $5(50 \%)$ & $1(10 \%)$ \\
\hline Hypertension & $5(50 \%)$ & $1(10 \%)$ \\
\hline Metabolism and nutrition disorder & $4(40 \%)$ & - \\
\hline Anorexia & $2(20 \%)$ & - \\
\hline Decreased appetite & $2(20 \%)$ & - \\
\hline Skin and subcutaneous tissue disorder & $4(40 \%)$ & - \\
\hline Rash & $3(30 \%)$ & - \\
\hline Dry skin & $2(20 \%)$ & - \\
\hline Erythema & $1(10 \%)$ & - \\
\hline Nail disorder & $1(10 \%)$ & - \\
\hline Onychoclasis & $1(10 \%)$ & - \\
\hline Nervous system disorder & $3(30 \%)$ & - \\
\hline Headache & $3(30 \%)$ & - \\
\hline *Renal and urinary disorder & $1(10 \%)$ & - \\
\hline Proteinuria & $1(10 \%)$ & - \\
\hline
\end{tabular}

Common adverse event is defined by that the frequency of the adverse event of all grades in that class is $15 \%$ or greater

* Typical side effects associated with the angiogenesis inhibitors
2 weeks were fatigue, dysphonia, hypertension, nausea, myalgia, and arthralgia (Table 2). Two patients experienced severe adverse events (SAE) (hypertension and abdominal pain) possibly related to aflibercept. Among the patients taking SC aflibercept, no deaths designated as possibly related to the drug were observed, and no patients were discontinued from the study due to treatment-related toxicity.

We examined toxicities possibly related to inhibition of VEGF. Hypertension was seen in 5 out of 10 patients with one subject experiencing grade 3 hypertension. The same subject also developed grade 1 proteinuria, as confirmed by $24 \mathrm{~h}$ urine collection. No grade 3 or 4 proteinuria events were observed.

Pharmacokinetics (PK) PK data of SC aflibercept at $4 \mathrm{mg} / \mathrm{kg}$ every 2 weeks were collected from 7 patients who had received at least 2 doses of aflibercept and completed by Day 22 . At the steady state, the mean plasma concentrations of the free aflibercept and bound aflibercept were $8.69 \mu \mathrm{g} / \mathrm{mL}$ and $4.49 \mu \mathrm{g} / \mathrm{mL}$, respectively (Fig. 1). The free/bound ratios at steady state was 1.74 , indicating an excess of free over bound aflibercept at SC dose levels of $4.0 \mathrm{mg} / \mathrm{kg}$ every 2 weeks. The PK profiles from patients receiving SC aflibercept fell into two distinct populations. The first group demonstrated a PK profile with a Cmax around $20 \mu \mathrm{g} / \mathrm{mL}$ and $t$ 1/2 ranging between 7 and 9 days, while the second group showed a Cmax rround $3-5 \mu \mathrm{g} / \mathrm{mL}$. The bound aflibercept exposure in the first group is higher than the second group.

Immunogenicity Anti-aflibercept antibodies were not detected in any patients.

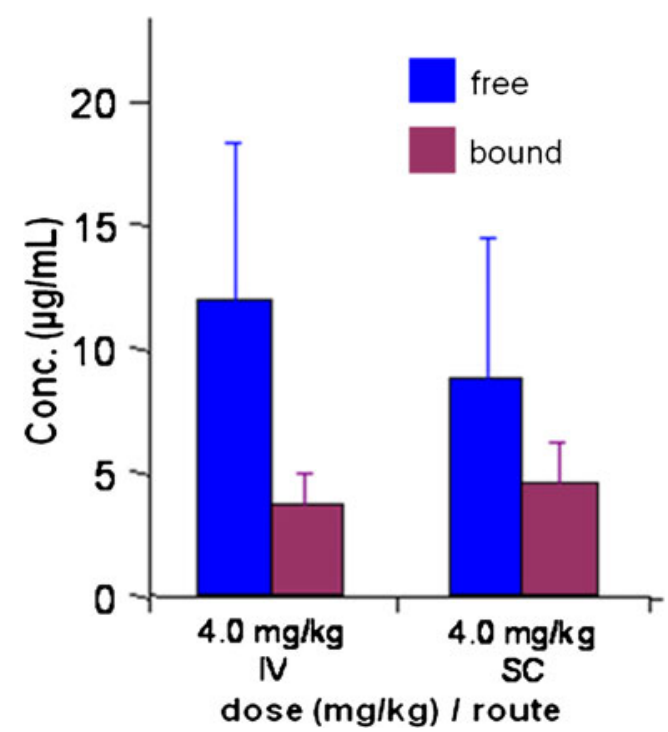

Fig. 1 Mean free and bound aflibercept SC $(n=7)$ and IV $(n=6)$ at $4 \mathrm{mg} / \mathrm{kg}$ concentration at steady state 
Efficacy Treatment efficacy was assessed in 5 patients who received at least one dose of aflibercept and had at least one post baseline assessment. Among 5 evaluable patients, 2 demonstrated stable disease. A 69-year-old woman with papillary serous carcinoma of the ovary had stable disease for 203 days. She was previously treated with multiple lines of chemotherapy including carboplatin, paclitaxel, liposomal doxorubicin, gemcitabine, and topotecan. The second patient was a 58-year-old woman with granulosa cell tumor of the ovary, and she had stable disease for 50 days. Three out of 5 had disease progression.

\section{Discussion}

Targeting angiogenesis is a mainstream anti-cancer therapy. The benefit of depleting of VEGF by aflibercept has been demonstrated in preclinical studies and early phase clinical trials [6-14]. Currently, multiple Phase III clinical trials using the aflibercept IV formulation in combination with other agents are ongoing. A dose of $4 \mathrm{mg} / \mathrm{kg}$ administered IV every 2 weeks has been recommended for future clinical trials [11].

Here, we report the toxicity, PK data and efficacy of the new $\mathrm{SC}$ formulation of aflibercept at $100 \mathrm{mg} / \mathrm{mL}$ from a phase I study. The sample size of 10 patients is adequate to assess toxicity of the new formulation, and the toxicities were found to be tolerable and reversible. Hypertension of any grade was seen in 5 patients $(50 \%)$ in the SC group, compared with 5 (71.4\%) out of 7 patients receiving intravenous aflibercept at $4 \mathrm{mg} / \mathrm{kg}$ [11]. Moreover, grade 3 and 4 hypertension was seen in $1(10 \%)$ out of 10 patients receiving SC aflibercept, compared with $3(42.9 \%)$ out of 7 patients receiving IV aflibercept. Grade 3 and 4 proteinuria possibly related to aflibercept were see in 1 out $10 \mathrm{SC}$ patients and 1 out 7 IV patients, respectively. PK data of aflibercept suggest adequate depletion of free circulating VEGF. At steady state, plasma concentrations of free aflibercept were higher than bound aflibercept indicating maximum ligand blockade and were generally similar to IV aflibercept administered at the same dose. Furthermore, the mechanisms contributing to two distinct PK profiles of SC aflibercept need to be further explored. Tumor control (stable disease) was seen in two out of five evaluable patients.

For future development, the SC route of aflibercept delivery may provide advantages over IV formulations, including time and resource conservation. SC administration may allow self-administration by patients at home, sparing the need for intravenous access, for specialized nursing care and a reduction in visits to the physician's office. Based on our study, further investigation of SC aflibercept in combination with chemotherapy is warranted.
Open Access This article is distributed under the terms of the Creative Commons Attribution Noncommercial License which permits any noncommercial use, distribution, and reproduction in any medium, provided the original author(s) and source are credited.

\section{References}

1. Hanahan D, Weinberg RA (2011) The hallmarks of cancer: the next generation. Cell 144:646-674

2. Ellis LM, Hicklin DJ (2008) VEGF-targeted therapy: mechanisms of anti-tumour activity. Nat Rev Cancer 8:579-591

3. Jain RK (2003) Molecular regulation of vessel maturation. Nat Med 9:685-693

4. Kuo CJ, Farnebo F, Yu EY, Christofferson R, Swearingen RA, Carter R, von Recum HA, Yuan J, Kamihara J, Flynn E et al (2001) Comparative evaluation of the antitumor activity of antiangiogenic proteins delivered by gene transfer. Proc Natl Acad Sci U S A 98:4605-4610

5. Holash J, Davis S, Papadopoulos N, Croll SD, Ho L, Russell M, Boland P, Leidich R, Hylton D, Burova E et al (2002) VEGF-trap: a VEGF blocker with potent antitumor effects. Proc Natl Acad Sci U S A 99:11393-11398

6. Byrne AT, Ross L, Holash J, Nakanishi M, Hu L, Hofmann JI, Yancopoulos GD, Jaffe RB (2003) Vascular endothelial growth factor-trap decreases tumor burden, inhibits ascites, and causes dramatic vascular remodeling in an ovarian cancer model. Clin Cancer Res 9:5721-5728

7. Fukasawa M, Korc M (2004) Vascular endothelial growth factortrap suppresses tumorigenicity of multiple pancreatic cancer cell lines. Clin Cancer Res 10:3327-3332

8. Hu L, Hofmann J, Holash J, Yancopoulos GD, Sood AK, Jaffe RB (2005) Vascular endothelial growth factor trap combined with paclitaxel strikingly inhibits tumor and ascites, prolonging survival in a human ovarian cancer model. Clin Cancer Res 11:6966-6971

9. Kim ES, Serur A, Huang J, Manley CA, McCrudden KW, Frischer JS, Soffer SZ, Ring L, New T, Zabski S et al (2002) Potent VEGF blockade causes regression of coopted vessels in a model of neuroblastoma. Proc Natl Acad Sci U S A 99:11399_ 11404

10. Leighl NB, Raez LE, Besse B, Rosen PJ, Barlesi F, Massarelli E, Gabrail N, Hart LL, Albain KS, Berkowitz L et al (2010) A multicenter, phase 2 study of vascular endothelial growth factor trap (Aflibercept) in platinum- and erlotinib-resistant adenocarcinoma of the lung. J Thorac Oncol 5:1054-1059

11. Lockhart AC, Rothenberg ML, Dupont J, Cooper W, Chevalier P, Sternas L, Buzenet G, Koehler E, Sosman JA, Schwartz LH et al (2010) Phase I study of intravenous vascular endothelial growth factor trap, aflibercept, in patients with advanced solid tumors. J Clin Oncol 28:207-214

12. Tew WP, Gordon M, Murren J, Dupont J, Pezzulli S, Aghajanian C, Sabbatini P, Mendelson D, Schwartz L, Gettinger S et al (2010) Phase 1 study of aflibercept administered subcutaneously to patients with advanced solid tumors. Clin Cancer Res 16:358366

13. Verheul HM, Hammers H, van Erp K, Wei Y, Sanni T, Salumbides B, Qian DZ, Yancopoulos GD, Pili R (2007) Vascular endothelial growth factor trap blocks tumor growth, metastasis formation, and vascular leakage in an orthotopic murine renal cell cancer model. Clin Cancer Res 13:4201-4208

14. Wachsberger PR, Burd R, Cardi C, Thakur M, Daskalakis C, Holash J, Yancopoulos GD, Dicker AP (2007) VEGF trap in combination with radiotherapy improves tumor control in $\mathrm{u} 87$ glioblastoma. Int J Radiat Oncol Biol Phys 67:1526-1537 